\title{
BRANDING DAN EKSISTENSI PRODUK (KAJIAN TEORITIK KONSEP BRANDING DAN TANTANGAN EKSISTENSI PRODUK)
}

\author{
Oleh: Muhamad Nastain \\ Staff Pengajar Ilmu Komunikasi Universitas Mercu Buana Yogyakarta \\ E-mail: nastaindongdjates@gmail.com
}

\begin{abstract}
The competition of the industrial world does not accommodate the stagnation of the product and brand. They that are not sensitive to the changes and challenges of the market will be run over by a competitor. The comprehensive and continuous efforts to maintain the brand are required. The existence of products which supported by the differentiation is the response to the fulfillment of market expectations. Consumers have the right fully to determine the product selection in the midst of intense competition between products. The branding process and the existence of products provide answers to the challenges of any change in the field of marketing. Branding strategy seeks to put the product on the competitive position with other products.

The study was conducted with descriptive qualitative method to collect the information that related to the concept of brand and product differentiation. Building the brand can be done by "building" a massive and continuous public trust or by "borrowing" or attaching with more established brands. However, the mindset changes of the businessman in the treatment of brand is the main keyword that put the brand as an asset. Furthermore, maintaining the brand equity in the upper scale is a priority. Placing the brand at the preferred and needed positionof consumers can be done by building a positive brand values and evaluating the consumer expectations.

Building the competence to win the competition with competitors requires the measurable "market plan". Products differentiation in packaging tha accordance with market segmentation, the offered variants (flavor) till by product placement in accordance with the segmentation must be done carefully.
\end{abstract}

Keyword: concept, branding, marketing, product, differentiation, equity

\begin{abstract}
Abstrak
Persaingan ddalam dunia industry tidak mengakomodir stagnasi produk dan brand. Mereka yang tidak peka dengan perubahan dan tantangan pasar akan terlindas oleh competitor. Diperlukan upaya menyeluruh dan terus menerus untuk mempertahnakan brand. Eksistensi produk ditopang dengan adanya differensiasi sebegai jawaban pemenuhan eksektasi pasar. Konsumen memiliki hak sepenuhnya untuk menentukan pilihan produk ditengah ketatnya persaingan antar produk. Proses branding dan eksistensi produk memberikan jawaban dari tantangan setiap perubahan dalam bidang pemasaran. Strategi branding berupaya menempatkan produk pada posisi bersaing kompetitif dengan produk lain.

Penelitian dilakukan dengan metode deskriptif kualitatif untuk menggali informasi terkait konsep brand dan differensiasi produk. Membangun brand dapat dilakukan dengan "membangun" kepercayaan publik secara massif dan kontinyu atau dengan "meminjam" atau melekatkan dengan brand yang sudah lebih mapan. Akan tetapi perubahan mindset pelaku usaha dalam memperlakukan brand menjadi kata kunci utama yakni menempatkan brand sebagai asset. Selanjutnya mempertahankan ekuitas brand berada dalam skala atas merupakan prioritas. Menempatkan brand pada
\end{abstract}


Diterbitkan oleh Program Studi IImu Komunikasi

Universitas Ahmad Dahlan Yogyakarta

posisi disukai dan dibutuhkan oleh konsumen dapat dilakukan dengan membangun nilai-nilai positive brand serta mengevaluasi ekspektasi konsumen.

Membangun kompetensi untuk memenangkan persaingan dengan competitor memerlukan “market plan" yang terukur. Differensiansi produk dalam packaging sesuai dengan segmentasi pasar, varian (rasa) yang ditawarkan sampai dengan penempatan produk sesuai dengan segmentasi harus dilakukan dengan cermat dan penuh perhitungan.

Keyword: Konsep, branding, pemasaran, produk, differensiai, ekuita.

\section{A. Pendahuluan}

Dunia industri dan bisnis berkembang dari waktu ke waktu dan melindas setiap elemen yang tidak siap dengan perubahan. Persaingan semakin ketat dan kompetitor semakin mempertajam ruang kompetisi dengan menghadirkan produk-produk yang mirip bahkan menyempurnakan yang sudah ada. Perubahan strategi bisnis untuk menjawab tantangan wajib dilakukan dikarenakan perubahan terjadi di segala lini. Persaingan pada era perdagangan bebas membuat perusahaan berlomba-lomba menciptakan sebuah produk yang menjadi konsumsi publik dalam skala besar.

Produk yang tidak mampu membaca peta perubahan dan pergeseran persaingan bisnis dengan melakukan penyesuaian strategi bisnis akan tertinggal. Salah satu contohnya adalah suatu produk atau perusahaan yang jika tidak berubah dalam waktu yang lama maka pembeli atau klien akan bosan, tidak melihat adanya inovasi, dan dapat berpindah ke produk pesaing yang mungkin sudah melakukan perubahan. Karena itu, perubahan dalam suatu perusahaan terhadap produknya perlu dilakukan, dan salah satu perubahan yang perlu diakukan adalah dengan melakukan rebranding produk.

Rebranding pada produk atau perusahaan dapat mempresentasikan perubahan dan pembaruan dalam beberapa hal di produk atau perusahaan tersebut. Rebranding dapat dilakukan dengan berbagai macam tidak hanya terbatas pada rebranding logo ataupun perubahan tagline iklan tetapi juga dapat dilakukan dengan diferensiasi produk. Upaya pendahuluan yang dilakukan oleh perusahaan yang akan melakukan rebranding adalah dengan melakukan riset yang mendalam akan kebutuhan pasar dan riset keinginan konsumumen. Proses evaluasi produk yang diluncurkan harus dikaji dan dianalisis agar semakin dibutuhkan dan disukai oleh konsumen.

Produsen dituntut melakukan riset yang mendalam untuk mengetahui keinginan konsumen atas produk yang dikeluarkannya. Oleh karena itu produsen menyediakan jasa pengaduan konsumen. Diharapkan dengan berbagai masukan dari konsumen dapat Dianalisis dan dievaluasi untuk memperbaiki sebuah produk.

Penelitian ini memiliki latar belakang kajian teoritik dan literatur dengan mempertimbangkan data-data lapangan sebagai penguat atas temuan-temuan teori. Hal ini dilakukan untuk mendekatkan asumsi teori yang berkembang dengan tataran aplikasi. Hakikatnya dalam perspektif ilmu pengetahuan antara teori dan aplikasi seharusnya memiliki kedekatan seperti adagium yang berlaku yakni "das sein dan sollen”. 


\section{B. Tinjauan Pustaka}

\section{Branding dan Rebranding}

Dalam Komunikasi pemasaran brand atau yang dikenal dengan brand bukan sekedar nama dan logo, brand merupakan janji satu organisasi (satuan kerja) kepada pelanggan untuk memberikan apa yang menjadi prinsip brand tersebut. Tidak hanya manfaat fungsional melaikan manfaat emosional, ekspresi diri dan social. Namun brand juga bukan hanya sekedar memenuhi janji. Brand adalah sebuah perjalan panjang yang berkembang berdasarkan persepsi dan pengalaman serta penilaian, kepuasan pelanggan terhadap pelayanan yang berhubungan dengan brand tersebut.

Menurut Kotler brand adalah sebuah nama, istilah, tanda, symbol, rancangan atau kombinasi semua unsur yang digunakan untuk mengenali produk atau jasa dari seseorang atau sebuah kelompok penjual dari pesaingnya ${ }^{1}$. Brand berfungsi sebagai satu ikatan yang kuat secara emosional antara pelanggan dan konsumen, tataran bagi opsi-opsi strategis dan kekuatan yang mempengaruhi financial.

Kekuatan brand atau brand telah mengikat loyalitas pelanggan sehingga menghantarkan keberhasilan bisnis, ketangguhan dan produk yang bersaing. Brand dengan segala kekuatannya memiliki makna yang berbeda-beda dengan tujuan yang berbeda pula. MarkPlus Institute of Marketing mengidentifikasi 6 (enam) tingkatan brand, yaitu: ${ }^{2}$

a. Atribut yakni sebuag brand yang diharapkan mampu mengingatkan suatu atribut atau sifat tertentu.

b. Manfaat yakni sebuah brand yang lebih dari seperangkat atribut.pelanggan tidak membeli atribut melainkan membeli manfaat baik yang fungsional (tahan lama) maupun emosional. Sebuah brand yang bagus tidak hanya memiliki kekuatan menjelaskan produk kepada pelanggan tetapi juga dibangun dengan konsistensi keunggulan produk. Pelanggan membeli sebuah produk tidak hanya berharap dari brandnya saja melainkan juga fungsi dari produk tersebut omotif.

c. Nilai yakni suatu brand menciptakan nilai bagi produsen. Nilai yang melekat pada produk biasanya dimaknai dengan cara yang sederhana tetapi mewakili keseluruhan sebuah produk. Pelanggan yang memakai gadget terbaru hendak menunjukkan dirinya sebagai sosok yang peduli teknologi, update dengan teknologi terbaru dan berusaha menaikkan prestisenya dengan produk yang dipakai.

d. Budaya, yakni suatu brand mewakili budaya tertentu. Misalkan Mercedes mewakili budaya Jerman yang efsisen dan berkualitas tinggi. Honda mewakili budaya Jepang yang sarat degan teknologi dan impian masa depan. Produk yang diproduksi dinegara dengan budaya tinggi dan tingkat kedisiplinan tinggi dan kualitas yang terjamin akan lebih meyakinkan daripada yang diproduksi di negara yang secara budaya, kualitas lebih rendah.

e. Kepribadian, yakni suatu brand juga mampu merancang kepribadian tertentu.

\footnotetext{
${ }^{1}$ Kotler Philip (2000), Marketing Management Millenium Edition, Prentice Hall International, Inc, Kotler,Phillip \& Amstrong, Gary (1996), Principles of Marketing.Prentice Hall.Inc

${ }^{2}$ Markplus Institute of Marketing (2009), Brand Operation, Jakarta : Erlangga
} 
Diterbitkan oleh Program Studi IImu Komunikasi

Universitas Ahmad Dahlan Yogyakarta

f. Pemakai, yakni suatu brand akan memberi kesan kepada pengguna brand tersebut. Kesan tersebut lahir dari pengalaman menggunakan produk. Kualitas produk yang tinggi akan memberikan kesan dan pengalaman yang positif bagi pemakai dan akan melahirkan loyalitas terhadap produk tersebut.

Sekitar akhir tahun 1980-an muncul sebuah ide dahsyat, yaitu pemikiran bahwa brand adalah asset, memiliki ekuitas dan menggerakkan strategi serta performa bisnis. Konsepsi brand sebagai asset menimbulkan arus perubahan yang dramatis dan besar pengaruhnya, mengubah persepsi pemasaran dan manajemen brand, bagaimana brand seharusnya dikelola dan diukur, dan peran para eksekutif pemasaran ${ }^{3}$.

Perusahaan yang mampu mengadopsi dan berhasil mengimplementasikan pandangan diatas dapat menyaksikan bahwa brand building beralih dari upaya taktis yang dapat didelegasikan dengan aman melalui satu tim komunikasi menjadi sebuah strategi penggerak bisnis.

Aaker menjelaskan konsep rebranding adalah suatu usaha komunikasi pemasaran yang dilakukan untuk memberikan suatu kepribadian baru kepada brand atau produk melalui perubahan tampilan dalam atau luarnya ${ }^{4}$. Sedangkan menurut Anholt kegiatan rebranding adalah proses merancang, merencanakan dan mengkomunikasikan ulang nama atau identitas produk atau jasa yang bertujuan untuk mengelola reputasi di masyarakat ${ }^{5}$. Kegiatan rebranding bagi perusahaan adalah sebuah keniscayaan yang harus dilakukan. Sekuat apapun posisi perusahaan tetaplah suatu saat harus melakukan rebranding baik karena faktor internal ataupun karena tekanan eksternal atau competitor.

\section{Metodologi Penelitian}

Penelitian ini menggunakan paradigma postpositivistik sebab berlandaskan pada filsafat postpositivisme. Yang dimaksud dengan filsafat postpositivistime yang juga biasa disebut sebagai pradigma konstruktifis adalah yang memandang realitas social sebagai sesuatu yang holistic, kompleks, dinamis, penuh makna dan hubungan yang bersifat interaktif (reciprocal). ${ }^{6}$

Paradigma ini merupakan paradigma yang relevan digunakan dalam penelitian ini. Karena peneliti ingin memahami dan mendeskripsikan bagaimana perusahaan melakukan strategi rebranding dan repositioning untuk menghadapi tantangan bisnis dimasa yang akan datang dan untuk meneguhkan eksistensi perusahaan melalui studi literatur.

Penelitian ini juga akan menerapkan pola berpikir induktif, yakni metode berpikir yang berpangkal dari hal-hal yang khusus (fakta empiris) menuju hal-hal yang umum

3 David AAker (2015), Aaker On Branding 20 Prinsip Esensial Mengelola dan Mengembangkan Brand, Jakarta : Gramedia Pustaka Utama, h. 3

${ }^{4}$ Aaker, David(1991), Manging brand Equity: Capitalizing on The Value of a Brand Name. New York: The Free Press

${ }^{5}$ Anholt, Simon (2007), Competitive Identity. The New Brand Management for nations, Cities and Regions, Palgrave Macmillan

${ }^{6}$ Sugiyono (2007), Metode Penelitian Kuantitatif, Kualitatif dan R\&D. Bandung: Penerbit Alfabeta 
(tataran konsep). Pola piker induktif ini akan meliputi: proses pengamatan, proses pengumpulan data, analisis data dan proses menarik kesimpulan. ${ }^{7}$

\section{PEMBAHASAN}

\section{Kajian Konsep Branding}

Kompetisi dalam dunia bisnis cenderung menggunakan hukum rimba yakni siapa yang paling kuat yang akan bertahan dan memenangkan persaingan. Kompetisi tidak memberikan ruang untuk kesalahan karena pasti akan langsung diberikan hukuman oleh pasar. Oleh karena tu diperlukan langkah-langkah sistematis dalam menyusun konsep branding baik produk barang maupun jasa. Adapun langkah-langkah yang dapat ditempuh adalah sebagai berikut:

a. Memperlakukan Brand Sebagai Asset Perusahaan

Brand atau brand bukanlah sesuatu yang hadir tanpa perhitungan yang matang, bukan sesutau yang hadir tanpa konsep melainkan dikonsep dengan kalkulasi yang tinggi dan tujuan jangka panjang yang terencana. Pada sekitar akhir tahun 1980-an muncul pemikiran bahwa brand adalah asset yang mampu menggerakkan, memiliki nilai dan mampu mendongkrak penjualan. Keberadaan brand sebagai identitas yang membagun dan menggerakkan dirasakan semakin menguat, mengingat semakin banyak konsumen loyal yang cenderung percaya pada brand-brand tertentu.

Berangkat dari pemahaman bahwa brand adalah asset yang perlu dijaga dan dipertahankan, maka perusahaan perlu melakukan langkah-langkah terkait dengan stabilitas dan citra. Lebih dari sekedar logo, nama dan susunan huruf, brand menempatkan janji perusahaan atau produsen pada produk tersebut. Selain itu sebuah brand juga merupakan perjalanan panjang yang disana terekam semua jejak langkah dalam proses, tumbuh dan berkembang bahkan pasang surut produk.

Brand yang kuat dan mapan memiliki hubungan emosional dengan pelanggan. Memberikan kepercayaan dan kepuasan serta pemenuhan ekspekatasi konsumen sesuai dengan segmentasi dan kelas sosial. Oleh karena itu dalam perjalanan sebuah brand selalu ada cerita tentang bagaimana pemenuhan terhadap selera pasar, kebutuhan konsumen. Produsen memerlukan kajian mendalam tentang pengembangan sebuah produk untuk menjawab tantangan ekspektasi konsumen. Sebagai contoh bagaimana PT. Wings selaku produsen Mie Instan Sedaap melakukan riset dan pengembangan terkait selera pasar. Terobosan juga diperlukan untuk menjaga brand tetap berada pada "rel" yang tepat tanpa keluar jalur dan membuka peluang bagi competitor untuk mengganggu kemapanan produk.

Differensiasi produk baik dari isi kemasan (packaging) ataupun rasa (varian) diharapkan mampu menjaga kompetensi produk dan memastikan loyalitas konsumen dengan memberikan banyak pilihan sesuai dengan daya beli dan kultur konsumsi. Masyarakat sektor bawah tentu memiliki budaya konsumsi dan belanja yang berbeda dengan kelas menengah keatas. Begitu pula dengan "market place" dimana brand mendapatkan produk.

\footnotetext{
${ }^{7}$ Krisyantono, Rachmat (2007). Teknik Praaktis Riset Komunikasi. Jakarta: Kencana
} 
Diterbitkan oleh Program Studi IImu Komunikasi

Universitas Ahmad Dahlan Yogyakarta

Dalam membangun dan mempertahankan brand yang sudah ada, ketersediaan produk dengan berbagai macam kemasan (packaging) merupakan metode paling sederhana dalam memenuhi kebutuhan konsumen. Dalam praktiknya, perusahaan penyedia produk bahkan sampai mengatur distribusi pada tempat-tempat terdekat dengan konsumen. PT. Wings pada divisi marketing mengenal istilah "motoris" untuk menjangkau tempat-tempat yang jauh dan lebih kedalam ${ }^{8}$.

Pandangan bahwa brand adalah asset adalah sebuah pemikiran yang valid dengan dukungan fakta-fakta empirik. Konsumen memberikan pilihan produk kepada brand berdasarkan penilaian dan pengalaman ketika menggunakan produk. Jika sudah menggunakan pendekatan pengalaman dan kepuasan maka harga tidak lagi menjadi prioritas. Biasanya brand akan mengatakan bahwa kepuasan sebanding dengan harga atau kita kenal sebuah adagium dalam dunia bisnis yaitu "uang tidak pernah salah". Kalimat tersebut menunjukkan bahwa kepuasan dan pengalaman terhadap sebuah produk menempati posisi dominan dalam loyalitas konsumen. Kepercayaan yang sudah ada perlu dijaga dan dibangun dengan selalu melakukan riset baik dalam skala kecil ataupun besar untuk mengetahui keinginan lebih lanjut dari konsumen.

Keberadaan customer service selain sebagai tempat aduan dan keluhan konsumen juga memiliki fungsi sebagai bank informasi terkait keinginan dan ekspektasi konsumen. Informasi yang terhimpun dapat diklasifikasi kemudian dijadikan bahan untuk diserahkan kepada unit-unit terkait. Marketing dapat menggunakan data tersebut untuk memetakan produk apa saja yang diminati dan dikeluhkan. Unit Riset dan Development dapat menggunakan data tersebut sebagai acuan awal pengembangan produk serta evaluasi terhadap produk yang sudah dipasarkan. Pada intinya semua informasi yang terhimpun dan disebarkan kepada unit-unit terkait dapat digunakan sebagai alat untuk mempertahankan brand yang sudah ada.

\section{b. Membangun Brand}

Menciptakan strategi-strategi portofolio brand yang efektif selalu menghadirkan tantangan. Portofolio brand perusahaan terkadang antara satu dengan yang lain saling memiliki keterkaitan sehingga bisa saling mendukung. Ada beberapa metode yang dapat digunakan untuk membangun brand, yaitu:

1) Membangun (built it)

Membangun brand tidaklah mudah tetapi bukanlah hal yang mustahil. Diperlukan kerja keras dan perencanaan yang matang untuk membangun brand yang kuat, khas dan berkarakter. Membangun brand dapat dilakukan dengan berbagai macam publikasi baik secara langsung (direct media) maupun secara tidak langsung (indirect media).

Direct media atau pengenalan brand secara langsung kepada publik dapat dilakukan dengan press conference, Press rilis dan Launching product. Ketiganya dilakukan dengan mengundang media untuk turut serta dalam

${ }^{8}$ Wawancara dengan Asisten Gudang PT. Wings Surya pada 20 Nopember 2016 pukul 21.00 wib 
memberitakan informasi terkait dengan munculnya produk baru. Iklan di berbagai media baik media konvensional maupun media online harus dilakukan mengingat daya jangkau media yang luas. Satu decade terakhir ini peran televise dan surat kabar yang pernah merajai iklan produk sudah mulai tergeser dengan hadirnya media online dengan beragam macamnya. Bahkan keberadaan surat kabar cetak menunjukkan trend semakin menurun dari waktu ke waktu. Sedangkan media online berkebalikan menunjukkan trend semakin positif. Hal ini perlu dicermati oleh perusahaan dalam menempatkan proporsi iklan.

Indirect media atau penggunaan media secara tidak langsung dapat dilakukan dengan menentukan opinion leader yang bertugas menyebarkan informasi dan membentuk opini publik. Opinion leader biasanya adalah tokoh yang dikenal secara luas oleh masyarakat dan dikenal memiliki kredibilitas unggul dalam bidangnya masing-masing. Opinion leader biasanya juga disebut brand ambassador sebagai ujung tombak perusahaan dalam memperkenalkan produknya kepada konsumen. Terkait dengan kredibilitas brand ambassador kenapa menjadi persoalan penting karena dalampembentkan opini dengan menggunakan indirect media menggunakan metode two step flow model atau dikenal dengan model dua arah. Opini publik terkait dengan produk dibentuk oleh brand ambassador bukanlah oleh produk itu sendiri sehingga kepribadian, dan kredibilitasnya harus terjaga.

2) Melekatkan

Cara membangun brand yang kedua adalah dengan melekatkan kepada brand yang sudah lebih mapan. Meminjam brand dengan melekatkan kepada produk lain lazim digunakan pada brand-brand yang baru saja rilis. Selain untuk mendongkrak penjualan juga dapat digunakan sebagai strategi memperkenalkan brand produk kepada konsumen.

Cara ini biasanya dilakukan oleh produsen grup yang memiliki banyak produk sehingga antara produk yang satu dengan yang lain dapat saling mendukung. Biasanya produk baru disertakan dalam penjualan pada produk yang lebih mapan sebagai bonus. Misal untuk memperkenalkan produk baru minuman "floridina" dan untuk mendongkrak penjualan, "floridina" dimasukkan dalam bonus pembelian "So Klin". Selain meminjam dan menggabungkan dengan produk lain yang sudah lebih mapan dapat diambil manfaat yang lain yaitu mencoba mendongkrak kepercayaan publik berdasarkan kesamaan nama besar produsen. Dikalangan konsumen ada beberapa yang memiliki pemikiran "fanatik" terhadap produsen. Apapun yang diproduksi oleh perusahaan tersebut seolah sudah menjadi jaminan mutu. Misal konsumen yang puas dan percaya dengan produk Mercy, maka seri apapun yang dirilis oleh Mercy diyakini pasti memiliki kualitas yang bagus. 
Diterbitkan oleh Program Studi IImu Komunikasi

Universitas Ahmad Dahlan Yogyakarta

\section{c. Menjaga Ekuitas Brand}

Ekuitas brand berbincang tentang meningkatnya nilai produk yang melekat pada brand sebagai hasil dari dukungan pelanggan untuk brand tertentu. Dalam perspektif perusahaan nilai ekuitas sangat terkait dengan eksistensi produk. Perusahaan berusaha menempatkan nilai produk pada posisi penting dalam perspektif konsumen. Semakin dinilai penting oleh konsumen maka akan semakin menempati posisi prioritas untuk dijadikan alasan untuk membeli.

Peningkatan nilai brand bukan hadir serta merta tanpa ada upaya yang bersifat sinergis dan sistematis. Peningkatan nilai harus dibangun serius disesuaikan dengan target dan perencanaan perusahaan. Penentuan segmentasi pasar dan mampu menjawab kebutuhan konsumen adalah langkah awal untuk menaikkan nilai brand. Selain itu perusahaan harus melakukan upaya terus menerus dan membangun opini publik secara massif sehingga mampu meyakinkan publik bahwa produk tersebut penting dan memiliki "keharusan" untuk dikonsumsi.

Misalkan produk susu sapi melakukan upaya membangun opini publik secara terus menerus dan massif dengan memberikan informasi tentang pentingnya susu sapi dan beragam manfaatnya. Seolah-olah tanpa minum susu sapi setiap hari maka masyarakat akan kehilangan sesuatu yang sangat penting. Ketika opini sudah terbangun dan semua elemen meyakini bahwa minum susu itu bukan sekedar baik buat kesehatan dan imunitas tetapi juga mampu meningkatkan kecerdasan maka masyarakat akan membeli produk susu sapi bahkan menempatkan produk susu sapi sebagai prioritas belanja.

Selain menggunakan iklan dan promosi secara massif pembentukan opini publik juga membutuhkan data-data berdasarkan riset akademis untuk meyakinkan konsumen. Merujuk pada teori kebenaran dalam filsafat pragmatisme John Dewey menyatakan bahwa salah satu metode untuk menguji kebenaran informasi adalah dengan teori kohenrensi yakni mencoba mencari keterkaitan antara proposisi-proposisi yang logis.

Nilai ekuitas dalam perspektif perdagangan (trade's perspektif) menempatkan produk pada kemampuan bersaing dengan competitor. Marketing selalu menghadirkan kompetisi antar produk. Hampir tidak ada produk yang menjadi pemain tunggal dalam dunia marketing karena semua produsen berlomba untuk saling merebut pasar sesuai dengan segmentasi produknya. Produk pemenang biasanya diidentifikasi dengan meningkatnya kesadaran merk (brand awareness) yakni kesanggupan konsumen untuk mengenali atau mengingat kembali brand dari suatu produk atau jasa perusahaan.

Brand awareness ditandai dengan pengenalan produk brand tersebut telah berada dalam pikiran paling utama (top of mind awareness) atau dengan kata lain brand tersebut menjadi brand yang paling diingat di dalam pikiran seseorang. Sering kita temui dalam kultur konsumen tanah air menyebutkan brand produk tertentu sebagai kata ganti dari jenis produk. Misalkan penyebutan air minum dalam kemasan (AMDK) sering diganti dengan sebutan "aqua". Penyebutan kata ganti sepeda motor dengan sebutan "Honda" dan lain sebagianya. Secara analisis sederhana dan sesuai dengan tingkatan kesadaran merek menunjukkan bahwa brand-brand yang telah bermetamorfosis menjadi sebutan jenis produk menempati posisi teratas dalam brand awareness.

Dalam perspektif konsumen secara individu (individual consumer's perspective) nilai ekuitas sebuah brand dapat terlihat dari brand awareness konsumen terhadap produk. 
Konsumen dengan mudah menjatuhkan pilihan kepada produk yang sudah diyakini kualitasnya berdasarkan pengalaman dan kepuasan ketika menggunakan produk tersebut. Setiap konsumen memiliki tipikal tersendiri dan individualistic terhadap sebuah produk. Dalam satu produk sabun cuci baju misalkan, seorang konsumen bisa memiliki kesenangan dan kepuasan terhadap banyaknya busa dan konsumen lain memiliki kepuasan karena harumnya. Oleh karena itu perusahaan sebagai penyedia produk dan jasa harus melakukan riset kepuasan pelanggan dan juga ekspektasi pelanggan terhadap sebuah produk.

\section{d. Mempertahankan Brand}

Sebuah brand diciptakan untuk bertahan dalam jangka waktu yang panjang bahkan direncanakan menjadi sebuah warisan yang dapat diturunkan. Dalam mengelola brand agar mampu bersaing dan memenangkna pertempuran dengan competitor dibutuhkan strategistrategi yang komprehensif dan langkah-langkah taktis menghadapi pertarungan pasar. Salah satu ancaman matinya brand adalah ketika konsumen tidak lagi mempertimbangkan brand sebagai salah satu opsi dalam daftar belanja. Hal itu dapat terjadi karena bermacam faktor mulai dari segmentasi pasar, harga yang kompetitif sampai pada pemenuhan selera pasar yang tidak terpenuhi.

Ancaman terhadap brand dapat terjadi karena subkategori atau kategori dimana brand tersebut melekat sedang mengalami penurunan. Akan terjadi dalam satu masa, bisnis terhadap sebuah produk mengalami penurunan yang signifikan. Sebagai contoh sektor yang sering mengalami penurunan dan kenaikan dikarenaka situasi dan kondisi adalah penjualan buku tulis dan peralatan sekolah. Setiap akhir tahun dan menjelang tahun ajaran baru produksi buku tulis dan peralatan sekolah akan mengalami kenaikan yang signifikan karena permintaan meningkat. Tetapi pada tengah tahun atau setelah masuk sekolah penjualan buku tulis dan alat sekolah akan mengalami penurunan signifikan. Naik dan turunnya penjualan produk berdasarkan segmentasi konsumen tersebut harus disikapi dengan strategi khusus karena sifatnya yang temporer.

Penurunan permintaan terkait sebuah brand juga bisa terjadi karena imbas produk yang dievaluasi konsumen. Banyak terjadi dalam dunia otomotif adanya "recall" produksi seri tertentu karena ada complain dari konsumen dan memang ada kekurangan dalam produksinya. Secara tidak langsung "recall" tersebut mempengaruhi nilai brand secara keseluruhan bukan sekedar pada seri produk yang dievaluasi.

Brand juga bisa kehilangan relevansinya jika muncul sebuah alasan untuk tidak membelinya. Hal tersebut bisa terjadi karena muncul sesuatu yang negative pada sebuah produk. Sifat negative dapat berupa menurunnya kualitas produk, penurunan kuantitas produk, kebijakan pasca penjualan dan evaluasi konsumen. Penurunan kualitas produk menempati posisi paling krusial bagi konsumen untuk tidak membeli produk. Beberapa produsen harus bertarung melawan stigma buruk tentang nilai kualitas sebuah produk. Misalkan produsen mobil Korea yang harus bertarung menempatkan diri sejajar dengan produsen Jepang dalam hal kualitas. Karena sampai hari ini masih ada stigma negative dan opini publik yang berkembang pada konsumen bahwa produk otomotif Korea secara kualitas masih diragukan.

Penurunan kuantitas produk juga dapat dijadikan analisis munculnya stigma negative produk. Biasanya berlaku pada industry "Food and Beverage" dimana kuantitas 
Diterbitkan oleh Program Studi IImu Komunikasi

Universitas Ahmad Dahlan Yogyakarta

juga menjadi titik acuan bagi konsumen. Perubahan harga (harga naik) sering dihindari oleh produsen karena secara langsung akan mengkoreksi penjualan, maka langkah strtaegis yang diambil adalah dengan mengurangi kuantitas produk sehingga masih masuk dalam kalkulasi profit. Akan tetapi penurunan kuantitas ini dalam waktu lanjut akan disadari oleh konsumen dan menciptakan stigma negative. Kepuasan konsumen yang tergerus akan mempengaruhi tingkat kepercayaan dan loyalitas konsumen kepada produk.

\section{Differensiasi Produk Sebagai Jawaban Eksistensi Produk}

Strategi branding dan differensiasi produk memiliki keterkaitan yang erat dengan segmentasi pasar dan ekspektasi konsumen. Terkait dengan segmentasi pasar, differensiasi adalah upaya produsen membaca kelas-kelas pasar dan kemampuan serta kebiasaan beli pelanggan. Sedangkan ekspektasi konsumen merupakan upaya perusahaan atau penyedia produk memenuhi selera konsumen dengan menghadirkan varian yang beragam, packaging disesuaikan dengan kemampuan beli konsumen.

Strategi differensiaisi produk penting dilakukan karena adanya pertarungan yang sengit antar competitor. Mereka yang tidak siap dengan perubahan dan kemampuan membaca pasar dengan melakukan riset dan development tidak akan mampu bertahan dari persaingan dengan competitor. Differensiasi produk berlaku dalam beberapa elemen, yaitu:

\section{- Packaging}

Differensiasi produk dalam kemasana (packaging) disesuaikan dengan ekspektasi konsumen. Kemasan yang beragam dengan berbagai macam ukuran dimaksudakan untuk memudahkan konsumen dalam menentukan pilihan dan tingkat daya beli. Masyarakat pedesaan dengan daya beli rendah disediakan packaging sachet renteng yang dapat dibeli satuan. Sachet dalam kemasan yang lebih besar mulai dari isi lima sampai 20 dimaksudkan untuk dipasarkan pada took-toko swalayan dengan segemntasi pasar kelas menengah kebawah.

\section{- Varian}

Perjalanan panjang sebuah brand dihiasi dengan pasang surut. Jika diukur dengan data marketing tentunya yang menjadi tolok ukur adalah tinggi rendahnya penjualan dalam kurun waktu tertentu. Beberpa faktor menjadi alasan turun naiknya performa brand. Perusahaan perlu melakukan riset dan audiensi terkait perkembangan pasar. Dengan datadata yang dimiliki perusahaan dapat menentukan kuantitas produksi varian tertentu yang diproduksi lebih banyak dan varian yang harus dikurangi terkait dengan permintaan pasar. Banyaknya varian rasa sebuah produk turut menjaga eksistensi produk di mata konsumen. Berikut ini varian rasa dari produk "Mie Sedaap"

\footnotetext{
${ }^{9}$ Wawancara dengan Asisten Gudang PT. Wings Surya pada 20 Nopember 2016 pukul 21.00 wib
} 


\section{- Product Segmen}

Product Segmen berbincang tentang pentingnya membaca segmentasi produk dan memetakan competitor serta upaya untuk memasuki semua segmen pasar dengan produk dari perusahaan yang sama. Strategi yang digunakan adalah dengan membuat produk sejenis dengan merek berbeda dan didesain untuk bermain pada segmen yang berbeda. Sebagai contoh produk Mie Instan dari PT. Wings Surya memilik dua merek yang berbeda dan memainkan peran pada segmen yang berbeda pula. Mie Instan Sedaap dengan varian yang lebih banyak memasuki segmen kelas menengah keatas dengan menjadi competitor dari produk yang lebih mapan, sedangkan mie instan Succes yang sama-sama produk dari PT. Wings Surya memasuki peta pasar segmen menengah kebawah dengan produk unggulan mie isi dua.

Sebagai perbandingan yang menguatkan asumsi penelitian bahwa mie Succes hanyalah produk dengan segmen dibawah pasar mie sedaap adalah dengan jumlah varian yang tidak terlalu banyak. Dari observasi yang dilakukan ditemukan varian mie success hanya menyediakan tiga varian rasa yaitu rasa ayam bawang, goring kremes dan kari ayam $^{10}$.

\section{Ancaman Eksistensi Brand}

Brand-brand yang mapan tidak memberikan jaminan akan selalu bertahan jika tidak mendapatkan perhatian yang serius. Dalam dunia bisnis dan marketing kekuatan promosi, penjagaan kualitas dan membangun komunikasi dengan konsumen adalah beberapa faktor yang perlu mendapat perhatian serius diantara faktor yang lain. Promosi (pra penjualan) dilakukan secara berkala, terencana dan memproduksi informasi baru dalam upaya pembentukan opini publik. Kegiatan promosi berusaha menanamkan brand produk dalam ingatan konsumen seperti yang dituturkan oleh Farquhar tentang "accessible brand attitude" yang dimaknai seberapa cepat sebuah individu dapat menyimpan merek dalam ingatannya.

"Positive brand" yang dibangun dengan promosi, iklan, publikasi dengan biaya yang tidak sedikit harus diimbangi dengan kualitas produk yang terjaga dan berkembang semakin lebih baik. Karena pengalaman konsumen dalam menggunakan produk berperan menjaga loyalitas. Bahkan kualitas produk akan semakin menghilangkan nilai uang yang harus dikeluarkan oleh konsumen. Adagium "uang tidak pernah bohong" merujuk pada kualitas akan selalu linier dengan harga yang harus dibayar. Semakin tinggi kualitas produk, semakin tinggi uang yang harus dikeluarkan untuk menebus produk tersebut.

Selanjutnya adalah membangun komunikasi dengan konsumen (after sales). Eksistensi brand dibangun dengan memberikan saluran komunikasi pada konsumen untuk menyampaikan keluhan dan tanggapan atas pengalaman menggunakan produk. Disini dapat dilakukan dengan strategi agresif dengan memberikan informasi "customer service" dalam iklan dan produk seperti yang sering kita jumpai dalam kemasan produk. Strategi agresif juga dapat dilakukan dengan aktif meminta masukan dari konsumen terkait kepuasan pelanggan dengan menelepon secara random untuk memastikan objektifitas data.

${ }^{10}$ Wawancara dengan Asisten Gudang PT. Wings Surya pada 20 Nopember 2016 pukul 21.00 wib 
Diterbitkan oleh Program Studi IImu Komunikasi

Universitas Ahmad Dahlan Yogyakarta

Startegi defensive atau bertahan dilakukan dengan hanya menunggu informasi dari konsumen. Dismaping itu tetap melakukan pembenahan dan meningkatkan kualitas produk dengan harapan tidak ada keluhan terkait kualitas produk.

Membina hubungan jangka panjang dengan pelanggan dilakukan untuk menjaga hubungan berkelanjutan dan menjaga relasi dan loyalitas konsumen. Memberikan jaminan atas layanan atau produk serta menciptakan hubungan personal dengan konsumen (customer relationship management) mendatangkan keuntungan secara psikologis serta memberikan kemudahan akses bagi konsumen untuk menyampaikan masukan terkait produk.

\section{Penutup}

\section{Kesimpulan}

Urgensi branding dalam pemasaran dikonstruksi dengan cara merubah mindset (pola pikir) dikalangan internal bahwa brand adalah asset yang sangat berharga. Sebuah asset perusahaan yang harus dijaga, dipertahankan nilai-nilainya sebagai bagian yang tidak terpisahkan dari kebutuhan konsumen. Untuk memenangkan persaingan pasar nilai-nilai ekuitas brand harus dikelola dengan terencana, strategis dan mampu menjawab tantangan ekspektasi konsumen.

Membangun brand dapat dilakukan setidaknya dengan dua langkah yaitu membangun brand dari awal atau meminjam (borrow it) dengan produk lain yang sudah lebih mapan. Keduanya memiliki kelebihan dan kekurangan masing-masing. Diperlukan pilihan strategi yang tepat disesuaikan dengan situasi, kondisi dan tantangan pasar.

Differensiasi produk difokuskan untuk mendekatkan produk pada konsumen dengan berbagai macam segmentasi dan daya beli. Differensiasi dapat berupa kemasan, varian atau rasa serta segmentasi produk untuk penguasaan lintas sektor konsumen. Strategi differensiaisi produk penting dilakukan karena adanya pertarungan yang sengit antar competitor. Mereka yang tidak siap dengan perubahan dan kemampuan membaca pasar dengan melakukan riset dan development tidak akan mampu bertahan dari persaingan dengan competitor. Eksistensi brand mendapat ancaman dari promosi, penjagaan kualitas dan membangun komunikasi dengan konsumen.

\section{Saran}

a. Untuk menjaga eksistensi produk perusahaan harus melakukan branding dengan promosi secara berkala dan sistematis.

b. Merubah pola pikir dalam memandang brand dengan menjadikan brand sebagai asset

c. Eksistensi produk dipertahankan semaksimal mungkin dengan melakukan promosi, menjaga kualitas dan membangun komunikasi dengan konsumen. 


\section{Daftar Pustaka}

Buku:

AAker, David (2015), Aaker on Branding 20 Prinsip Esensial Mengelola dan Mengembangkan Brand, Jakarta: Gramedia Pustaka Utama

Aaker, David (1991), Manging brand Equity: Capitalizing on The Value of a Brand Name.

New York: The Free Press

Anholt, Simon (2007), Competitive Identity. The New Brand Management for nations,

Cities and Regions, Palgrave Macmillan

Krisyantono, Rachmat (2007). Teknik Praaktis Riset Komunikasi. Jakarta: Kencana

Markplus Institute of Marketing (2009), Brand Operation, Jakarta: Erlangga

Philip, Kotler (2000), Marketing Management Millenium Edition, Prentice Hall

International, Inc, Kotler, Phillip \& Amstrong, Gary (1996), Principles of Marketing.Prentice Hall.Inc

Sugiyono (2007), Metode Penelitian Kuantitatif, Kualitatif dan R\&D. Bandung: Penerbit Alfabeta

\section{Jurnal:}

http://midjournal.com/2014/01/perlukah-rebranding-logo-pada-suatu-produk-atauperusahaan/ diakses pada 31 Agustus 2016 